\title{
Review Article \\ Exploitation of Bacterial Activities in Mineral Industry and Environmental Preservation: An Overview
}

\author{
Ahmed A. S. Seifelnassr ${ }^{1}$ and Abdel-Zaher M. Abouzeid ${ }^{2}$ \\ ${ }^{1}$ Department of Mining Engineering, Faculty of Petroleum and Mineral Engineering, Suez Canal University, Suez 62114, Egypt \\ ${ }^{2}$ Department of Mining Engineering, Faculty of Engineering, Cairo University, Giza 12613, Egypt
}

Correspondence should be addressed to Abdel-Zaher M. Abouzeid; abdel.abouzeid@gmail.com

Received 14 August 2013; Revised 21 October 2013; Accepted 4 November 2013

Academic Editor: Morteza Osanloo

Copyright ( 2013 A. A. S. Seifelnassr and A.-Z. Abouzeid. This is an open access article distributed under the Creative Commons Attribution License, which permits unrestricted use, distribution, and reproduction in any medium, provided the original work is properly cited.

\begin{abstract}
Since the identification and characterization of iron and sulfur oxidizing bacteria in the 1940s, a rapid progress is being made in minerals engineering based on biological activities. Microorganisms can play a beneficial role in all facets of minerals processing, from mining to waste disposal and management. Some of the applications, such as biologically assisted leaching of copper sulfide ores, uranium ores, and biooxidation of refractory sulfide gold ores, are now established on the scale of commercial processes. A variety of other bioleaching opportunities exist for nickel, cobalt, cadmium, and zinc sulfide leaching. Recently, other uses of microorganisms are potentially possible. These include the bioleaching of nonsulfide ores, bioflotation, and bioflocculation of minerals, and bioremediation of toxic chemicals discharged from mineral engineering operations. These activities acquire considerable opportunities for further research and development in these areas. This paper is an attempt to provide a critical summary on the most important efforts in the area of bacterial activities in the mineral and mining industry.
\end{abstract}

\section{Introduction}

Biotechnology has many potential applications in mining industry including metal leaching, product upgrading, removal of impurities, treatment of acid rock drainage, and other uses for environmental control. Recent interest in the biotechnological processes is the direct application to treat wastes and low-grade ores [1-3]. In this aspect, bacteria catalyze the dissolution of metals from minerals. Therefore, bacterial leaching processes are faster than chemical processes at ambient temperature and atmospheric pressure. So far, only three different types of commercial scale microbiological leaching techniques are practiced for the recovery of copper and uranium from low-grade ores, namely, dump leaching, heap leaching, and insitu leaching. Knowledge about bacterial involvement in these processes has been relatively recent, because the microorganisms responsible for the solubilization of metals from minerals were identified only a few decades ago. Furthermore, heap and dump leaching technologies were introduced in the United States by the Phelps-Dodge Corporation at Bisbee, Arizona, and
Tyron, New Mexico, in early 1920s [4], although at that time the processes involved in the leaching and acid drainage production were considered to be solely chemical in nature.

Lately, interest in the biological oxidation of refractory sulfide gold ores has been practiced worldwide [5]. Moreover, microorganisms are used in biobeneficiation which refers to removal of undesirable mineral components from an ore. The interaction with microorganism selectively removes the impurities, and thereby enriches the desired mineral constituent in the solid ore matrix such as, biodesulfurization of coals and biobeneficiation of iron ores. Another potential utilization of microorganisms is that they could be used to flocculate finely divided minerals and/or be used as mineral surface modifiers or flotation collectors.

\section{Bioleaching of Sulfide Ores}

2.1. Microorganisms Involved in Leaching Processes. The most important group of bacteria which are involved in sulfide minerals leaching are the acidophilic Thiobacilli which 
belongs to the family Thiobacteriacrae. They have the ability to use the oxidation of inorganic sulfur and its compounds to produce energy for growth. They are, therefore, referred to as chemolithotrophs. They include the autotrophs which derive their carbon for growth solely from carbon dioxide, mixotrophs that can utilize carbon derived from organic compounds, and carbon dioxide, and the heterotrophs whose sole source of carbon is obtained from organic substrates. The majority of the Thiobacilli species are active between 30 and $35^{\circ} \mathrm{C}$. However, moderately thermophilic species have been isolated which grow best at temperature of $45-50^{\circ} \mathrm{C}$ [6].

In order of importance, the Thiobacilli which are involved in mineral leaching are Acidithiobacillus ferrooxidans, Thiobacillus thiooxidans, Thiobacillus acidophilus, and Thiobacillus oranoporus. Acidithiobacillus ferrooxidans is the most important of the above species [7-9]. This species is able not only to utilize inorganic sulfur compounds but also to oxidize ferrous iron in inorganic substrates. Their differentiation is based upon their capacity to oxidize either elemental sulphur or various sulfide minerals.

Acidithiobacillus ferrooxidans is an aerobic, acidophilic autotrophic, Gram-negative, bacterium. It is rod-shaped bacterium and is active above $\mathrm{pH} 2.0$ [10]. Mesophilic strains have an optimum temperature of $35^{\circ} \mathrm{C}$ for growth. It requires a source of nitrogen, phosphate, and trace amounts of calcium, magnesium, and potassium. Its energy for growth is obtained from the oxidation of ferrous iron, insoluble sulfides, and soluble sulphur compounds. The $9 \mathrm{~K}$ nutrient medium was derived for mass production of Acidithiobacillus ferrooxidans cells [11]. There are also some Acidithiobacillus ferrooxidans species which are also acidophilic, autotrophic, rod shaped, mesophilic bacteria, which grow on elemental sulfur, and soluble sulfur compounds, but unable to oxidize ferrous iron or insoluble sulfides.

Thiobacillus acidophilus and Thiobacillus oranoporus are mesophilic, mixotrophic, acidophilus rod-shaped bacteria that oxidize only elemental sulfur for growth. They grow at $\mathrm{pH}$ 1.5-5.0 with an optimum value from 2.5 to 3.0. Being unable to oxidize insoluble sulfides, their role in mineral leaching may only be to consume organic compounds excreted by Acidithiobacillus ferrooxidans which are detrimental to the latter organism's growth [12].

In recent years, moderately and extremely thermophilic and acidophilic bacteria which are able to oxidise iron, sulfur and mineral sulfides have been isolated and tested [6, 13-15]. Moderately thermophilic Thiobacilli have been demonstrated to be heterotrophic with optimum temperatures for growth between 45 and $60^{\circ} \mathrm{C}$. Strains of thermophilic organisms of a Sulfolobus type grow within a temperature range of $55-85^{\circ} \mathrm{C}$. Their role in solubilizing metal is not completely understood. However, the usefulness of thermophilic microorganisms can also be extended to bioremediation activities.

2.1.1. Mechanisms of Bioleaching. Some doubt still surrounds the exact role of bacteria in the oxidation of sulfide minerals because of the inability to discretely separate reactions which are solely promoted by bacteria from those which are simply chemical. The concept of direct and indirect modes of bacterial leaching of metal sulfides (MS) was introduced few decades ago [10].

In the direct mode of bacterial leaching mechanism, the sulfide is oxidized to metal sulfate:

$$
\mathrm{MS}+2 \mathrm{O}_{2} \stackrel{\text { bacteria }}{\longrightarrow} \mathrm{MSO}_{4}
$$

where $\mathrm{M}$ is a bivalent metal. The heavy metal sulfides are generally insoluble in aqueous acid leach media while their sulfates are soluble. In some cases, the oxidation product is insoluble as, for example, in the case of lead sulfide leaching. This fact can be utilized for selective leaching [16] to separate soluble zinc, copper, and cadmium from insoluble lead. In the direct mode of bacterial oxidation, bacteria must remain close to the surface of the solid substrate.

In the indirect mode, ferric ion produced from bacterial oxidation of pyrite, which is always associated with sulfide minerals, is the oxidant. The sequence of reactions is as follows:

$$
\begin{gathered}
2 \mathrm{FeS}_{2}+7.5 \mathrm{O}_{2}+\mathrm{H}_{2} \mathrm{O} \stackrel{\text { bacteria }}{\longrightarrow} \mathrm{Fe}_{2}\left(\mathrm{SO}_{4}\right)_{3}+\mathrm{H}_{2} \mathrm{SO}_{4} \\
\mathrm{MS}+\mathrm{Fe}_{2}\left(\mathrm{SO}_{4}\right)_{3} \stackrel{\text { chemical }}{\longrightarrow} \mathrm{MSO}_{4}+\mathrm{S}^{\mathrm{o}}+2 \mathrm{FeSO}_{4} \\
2 \mathrm{FeSO}_{4}+\mathrm{H}_{2} \mathrm{SO}_{4}+0.5 \mathrm{O}_{2} \stackrel{\text { bacteria }}{\longrightarrow} \mathrm{Fe}_{2}\left(\mathrm{SO}_{4}\right)_{3}+\mathrm{H}_{2} \mathrm{O} \\
\mathrm{S}^{\mathrm{o}}+1.5 \mathrm{O}_{2}+\mathrm{H}_{2} \mathrm{O} \stackrel{\text { bacteria }}{\longrightarrow} \mathrm{H}_{2} \mathrm{SO}_{4}
\end{gathered}
$$

In the absence of bacteria, elemental sulfur deposited on the surface of the particles may grow in proportion so as to create a thick enough layer to inhibit the progress of the leaching process. The sulfuric acid produced may further react with the oxide contents (MO) of the ore, thus contributing to the metal dissolution process:

$$
\mathrm{MO}+\mathrm{H}_{2} \mathrm{SO}_{4} \stackrel{\text { chemical }}{\longrightarrow} \mathrm{MSO}_{4}+\mathrm{H}_{2} \mathrm{O}
$$

An example of indirect bacterial leaching activity is the oxidation of chalcopyrite, $\mathrm{CuFeS}_{2}$, in the presence of pyrite. In this process, the copper mineral is leached in the presence of bacteria in the following manner:

$$
\mathrm{CuFeS}_{2}+2 \mathrm{Fe}_{2}\left(\mathrm{SO}_{4}\right)_{3} \stackrel{\text { chemical }}{\longrightarrow} \mathrm{CuSO}_{4}+5 \mathrm{FeSO}_{4}+2 \mathrm{~S}^{\mathrm{o}}
$$

Again the reaction by-products ferrous iron and sulfur are oxidized by bacteria to ferric iron and sulfuric acid following reactions (4) and (5).

The growth of Acidithiobacillus ferrooxidans is measured by cell count of the supernatants of the suspensions, whereas the extent of bacterial attachment/adsorption to minerals during leaching was estimated from cell protein concentration of the solid and liquid phases. Probable mechanism of attachment and detachment of bacteria was also discussed $[17,18]$. Recently, a two-step mechanism for bioleaching was proposed $[19,20]$. It involves chemical ferric reaction with the mineral to produce ferrous salt, and then bacterial oxidation of ferrous iron to ferric completes a closed loop of reactions. 
2.1.2. Developments in Bioleaching of Sulfide Ores. In 1947, Acidithiobacillus ferrooxidans, the main microorganism responsible for metal sulphide oxidation was first isolated and characterized [21]. It was found that this bacterium could oxidize the sulfide part of the mineral to sulfuric acid and the ferrous ion to ferric ion. This oxidation ability can be demonstrated in the oxidation of pyrite, which is almost always found with the sulfide minerals equation (2).

The bioleaching of pyrite will be discussed later when referring to coal desulfurization in Section 4 entitled biobeneficiation. Numerous systematic studies [22-25] have subsequently revealed that Acidithiobacillus ferrooxidans, under acidic leaching conditions, can attack most sulfide minerals, producing water-soluble metal sulphates. The optimum leaching conditions can be summarized as follows: growth media (nutrients) [26, 27], temperature $35^{\circ} \mathrm{C}[28,29], \mathrm{pH} 2.3$ [30], Eh below $500 \mathrm{mV}$ in order to avoid jarosite precipitation $[31,32]$, high specific surface area of solids [33, 34], and prior adaptation of bacteria to specific substrate $[23,35,36]$. Large scale heap and dump leaching operations were built so as to provide the best growth conditions for the microorganisms in order to harvest their beneficial effects in dissolution of metal from mining wastes $[37,38]$.

Most investigations concerning the bioleaching of copper from low-grade ores have been conducted in the laboratory using small columns or simulated in large scale tests. The influence of variations in the mineralogical composition and textural features of copper ores as well as process variables have been examined $[39,40]$. Chalcopyrite is leached in the presence of bacteria in (7).

Again, the above reaction by-products, ferrous iron and sulfur, are oxidized by bacteria to ferric iron and sulfuric acid.

The oxidation mechanisms for chalcocite $\left(\mathrm{Cu}_{2} \mathrm{~S}\right)$ can be expressed by the following equation:

$$
\begin{gathered}
\mathrm{Cu}_{2} \mathrm{~S}+0.5 \mathrm{O}_{2}+\mathrm{H}_{2} \mathrm{SO}_{4} \stackrel{\text { bacteria }}{\longrightarrow} \mathrm{CuS}+\mathrm{CuSO}_{4}+\mathrm{H}_{2} \mathrm{O} \\
\mathrm{CuS}+2 \mathrm{O}_{2} \stackrel{\text { bacteria }}{\longrightarrow} \mathrm{CuSO}_{4}
\end{gathered}
$$

In addition, extensive studies were conducted with thermophilic microorganism in the temperature range of 45$85^{\circ} \mathrm{C}$ [41-43]. The advantage of using thermophilic organisms in the leaching of sulfide minerals is that, at higher temperature, the reaction kinetics is expected to increase. A new genus of thermophilic spore-forming bacteria, sulfobacillus, was reported [43].

Due to the refractory nature of the chalcopyrite, the utilization of high temperatures and thermophilic bacteria has been investigated. It is reported that typical copper extraction yields obtained by mesophilic bacteria are about $30 \%$, whereas copper extraction yields of more than $98 \%$ can be obtained in shorter periods by thermophilic bioleaching $[44,45]$. A study concerning bioleaching of chalcopyrite showed that the bioleaching of chalcopyrite is controlled by the oxidation-reduction potential, temperature, $\mathrm{pH}$, and the activity of the thermophile used [46, 47].

Recently, a comparative study [48] on the bioleaching of chalcopyrite concentrates using mesophilic and moderately thermophilic bacteria indicated that the moderately

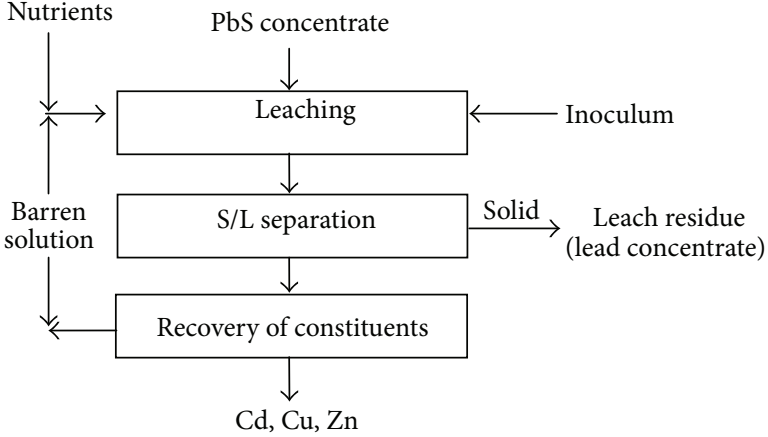

FIGURE 1: Schematic representation of a selective bacterial leaching process of a complex lead sulfide concentrate (S/L signifies solidliquid separation) [16].

thermophilic bacteria have higher ability for copper dissolution. These results show that copper dissolution from the chalcopyrite concentrate reached $87.52 \%$ with the moderately thermophilic bacteria while it was $34.55 \%$ with mesophilic culture after 25 days.

The applicability of bacterial leaching technique to the recovery of uranium from low-grade ores has been investigated $[49,50]$. In bacterial leaching of uranium ores, the tetravalent uranium is oxidized to its hexavalent state, which is soluble, by ferric sulfate:

$$
\begin{aligned}
& \mathrm{UO}_{2}+\mathrm{Fe}_{2}\left(\mathrm{SO}_{4}\right)+2 \mathrm{H}_{2} \mathrm{SO}_{4} \\
& \stackrel{\text { chemical }}{\longrightarrow} \mathrm{H}_{4}\left[\mathrm{UO}_{2}\left(\mathrm{SO}_{4}\right)_{3}\right]+2 \mathrm{FeSO}_{4}
\end{aligned}
$$

The role of bacteria is to reoxidize ferrous iron to the ferric state. Ferric sulfate is obtained by metabolic oxidation of pyrite, which is always present in the uranium ores. Bioleaching of copper and uranium ores by heap leaching resulted in substantial saving in the production costs.

Bioleaching of zinc sulfide concentrates using bacteria has been investigated $[16,51]$. The following reaction is proposed:

$$
\mathrm{ZnS}+2 \mathrm{O}_{2} \stackrel{\text { bacteria }}{\longrightarrow} \mathrm{ZnSO}_{4}
$$

The maximum rate of zinc extraction, under optimum conditions, was around $640 \mathrm{mg} / \mathrm{dm}^{3} \mathrm{~h}$ in terms of specific surface area, particle size, and pulp density of the solid substrate. Selective extraction of zinc, copper, and cadmium from below the cut-off grade (complex) lead sulfide concentrates is illustrated in the flow diagram in Figure 1. The method is especially applicable to ores with very fine crystalline intergrowth of lead, zinc, cadmium, and copper sulfides where quantitative recovery from individual mineral fractions is not possible by physical separation techniques. The leach residue in $\mathrm{PbS}$ concentrate leaching in this operation is a highgrade lead concentrate, which consists of unreacted $\mathrm{PbS}$ and insoluble $\mathrm{PbSO}_{4}$. The recovery step my involve precipitation of iron by increasing the $\mathrm{pH}$ to 3.5 using lime. Copper and cadmium are obtained by cementation and zinc hydroxide is precipitated by increasing $\mathrm{pH}$ value to 7.5 using magnesia. Zinc hydroxide can be converted to zinc by acidification and electrowinning $[16,23,35,52]$. 
Almost complete extraction of pentlandite, using the microorganisms Acidithiobacillus ferrooxidans, can be expressed by

$$
\begin{aligned}
& (\mathrm{Ni}, \mathrm{Fe})_{9} \mathrm{~S}_{8}+17.625 \mathrm{O}_{2}+3.25 \mathrm{H}_{2} \mathrm{SO}_{4} \\
& \stackrel{\text { bacteria }}{\longrightarrow} 4.5 \mathrm{NiSO}_{4}+2.25 \mathrm{Fe}_{2}\left(\mathrm{SO}_{4}\right)_{3}+3.25 \mathrm{H}_{2} \mathrm{O}
\end{aligned}
$$

It was possible to dissolve cobalt and nickel at a high rate from the sulfide minerals and to produce $\mathrm{Co}^{+2}$ and $\mathrm{Ni}^{2+}$ ion concentrations as high as $30 \mathrm{~g} / \mathrm{dm}^{3}$ and $71 \mathrm{~g} / \mathrm{dm}^{3}$, respectively. Selective extraction of arsenic from a complex, finely disseminated stannic, auriferous, zinc-copper ore has been described $[16,53]$. A basic flow diagram of this process is shown in Figure 2. In this process the arsenic content of the ore is solubilized by bacteria and, after solid-liquid separation, it is precipitated by addition of lime to raise the $\mathrm{pH}$ to about 3.0. The dissolved copper is recovered by cementation with scrap iron and the solution is recycled. From the solid residue of bacterial leaching, the unreacted copper ore is removed by flotation, yielding copper sulfide concentrate and a tin enriched residue. The process in Figure 2 can also be applied for leaching of gold-arsenic sulfides from finely disseminated metal in the sulfide matrix. In this case, the precious metals remain in the residue from bacterial leaching. The residue is neutralized by addition of lime and treated with cyanide solution to dissolve gold and silver. From the leach solution, arsenic is precipitated and discarded. The bacterial leaching in these studies can be considered as a preoxidation step which exposes the precious metals for subsequent cyanidation or thiourea leaching [5].

Lately, bacterial leaching methods gained further impetus with the introduction of biopreoxidation processes for the liberation of precious metals from sulfide-bearing minerals [54-56]. If gold occurs in a finely disseminated form within the sulfide ore matrix, the economic viability of conventional gold extraction processes by cyanide leaching becomes less than marginal. Extensive research work has been carried out for the treatment of the complex gold-bearing sulfide ores. It is reported that pyrite oxidation by bioleaching improved gold recovery. This promising improvement was proportional to the degree of oxidation (Figure 3). For example, with $84 \%$ oxidation of pyrite, gold recovery in solution reached $81 \%$.

Bioleaching research has demonstrated that microorganisms can tolerate exceptionally high metal ion concentration $(120 \mathrm{~g} / \mathrm{L}$ zinc, $72 \mathrm{~g} / \mathrm{L}$ nickel, $30 \mathrm{~g} / \mathrm{L}$ cobalt, $55 \mathrm{~g} / \mathrm{L}$ copper, and $12 \mathrm{~g} / \mathrm{L} \mathrm{U}_{3} \mathrm{O}_{8}$ ) and high hydrogen ion concentration (acid media of $\mathrm{pH}$ range 1-5) during leaching of sulfide minerals [43].

Genetic manipulations of leaching organisms were initiated in the eighties $[16,58]$. The purpose of these studies was to develop specific metal extraction using microorganisms capable of a high rate of metabolic conversion and resistant to toxic elements. Biosorption technology using free or immobilized alive or dead cells or their derivatives in films, aggregates, or pellets was illustrated. It was found that biosorption technology is especially applicable to the removal of toxic metal contamination from large volume of industrial

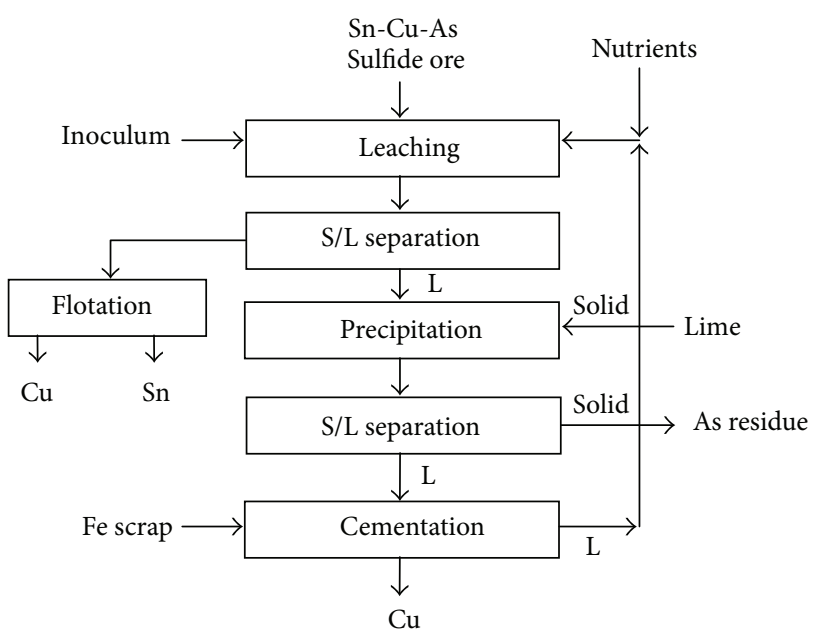

FIGURE 2: Bacterial leaching process for difficult-to-dress $\mathrm{Sn}-\mathrm{As}-\mathrm{Cu}$ ores [16].

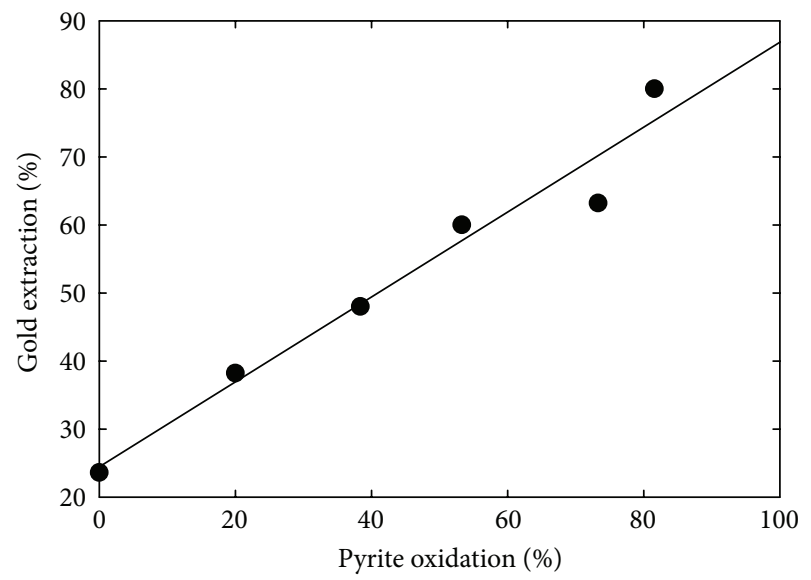

FIGURE 3: Effects of biological pyrite oxidation on gold recovery from Porgera concentrate [57].

waste streams containing trace amounts of heavy metals and radionuclide [59].

\section{Bioprocessing of Refractory Gold Ores}

Bacterial leaching processes will be significant in the treatment of difficult-to-process refractory ores [60-63]. The gold in refractory ores is encapsulated as fine particles in the crystal structure of sulfide matrix such as pyrite $\left(\mathrm{FeS}_{2}\right)$ and arsenopyrite (FeAsS). This makes the efficiency of the cyanidation process very low since the cyanide solution cannot penetrate the sulfide-bearing gold crystals and dissolve gold particles, even after fine grinding. Therefore, an oxidative pretreatment is necessary to decrease the refractory properties of the ore. Roasting is sometimes used, but it is highly energy consuming and involves a costly off-gas neutralization system to prevent atmospheric pollution $[64,65]$. Both pressure oxidation and oxidation by nitric acid require high temperature and/or corrosion-resistant materials which are costly items. Hence, biological pretreatment becomes an 
interesting alternative route. This route leads to environmental protection and low-cost processes [64]. Research and developments in this direction have been stimulated by the buoyant price of the precious metal and also by the fact that conventional methods of extraction are not able to produce a sufficiently high recovery of the contained value [66]. It has been demonstrated by both laboratory and pilot test work that such process is feasible [67]. The biological pretreatment of refractory gold ores is based on the ability of some microorganisms such as Acidithiobacillus ferrooxidans and Thiobacillus thiooxidans to oxidize and dissolve the bearinggold sulfide minerals, thus liberating the entrapped gold particles, thereby rendering it amenable to the cyanidation process $[57,64]$. Advancements in this area have been made on industrial scale to improve the rate of oxidation and to reduce cyanide consumptions in downstream gold recovery [68]. The results indicated a direct relationship between the degree of sulphide mineral oxidation and percent gold recovery. Complete oxidation of sulphides is not necessary to achieve significant enhancement of gold recovery. On the basis of the sulphide entity, high gold recoveries can be obtained with as low as $50 \%$ oxidation of the total sulphides.

\section{Biobeneficiation}

Biobeneficiation refers to removal of undesirable mineral components from an ore through interactions with microorganisms which bring about their selective removal by a bioleaching process. Compared to bioleaching of sulfide minerals by Thiobacilli, bioleaching of nonsulfide minerals has received little attention in the past. For example, desulfurization of coal, bioleaching of aluminum from aluminosilicates, removal of alumina and silica from iron ores, and so forth have been extensively studied. These interactions lead to enriching these desired mineral constituents in the solid ore matrix mediated by a number of surface chemical and physiochemical phenomena. The mediation roles include alteration of the surface chemistry of minerals, generation of metabolic products which cause chemical dissolution, selective dissolution of mineral phases in an ore matrix, and sorption, accumulation, and precipitation of ions and compounds on solid surfaces.

In order to minimize the potential deleterious impact of increased amounts of sulfur dioxide emission due to coal burning, the sulfur content of coal must be reduced. The biodesulfurization of coal presents a potentially attractive alternative to chemical and physical methods $[60,69,71]$. In the biodesulfurization process, the pyrite content of coal will be oxidized to water-soluble ferric sulfate and sulfuric acid according to (2). The dissolved ferric sulfate is removed from the coal in the dewatering step. The coal is then washed and dried prior to combustion.

Experimental investigations indicated that bacteria and fungi could be effectively used to remove iron and silica from clays, sands, and bauxite ores $[15,72,73]$. Successful commercialization of bauxite biobeneficiation was proposed [74]. Biological removal of calcium and iron from a lowgrade bauxite ore was discussed with respect to Bacillus polymyxa. Growth conditions and probable mechanisms in the biological removal of calcium and iron from the bauxite ore were outlined by Anand et al. [75]. From the reported results, changes in the $\mathrm{pH}$ of the leach medium correlated well with the calcium dissolution. The presence of bacteria lowers the $\mathrm{pH}$ and hence facilitates calcium dissolution.

Iron ores generally contain alumina, silica, sulfur, and phosphorous as the main gangue minerals. These impurities have adverse effects on reducibility of iron oxides, coke rate consumption, and blast furnace operation and productivity for steel making. Various studies have examined the use of the heterotrophic bacteria and fungi for removal of alumina and silica from iron ores for improving the iron content of the concerned ore. The iron ore beneficiation was carried out by secondary metabolites produced by these heterotrophic microorganisms [76, 77]. It has been reported that in situ leaching of an iron ore with fungal strains such as Aspergillus fumigatus, Penicillium citrinum, and Aspergillus flavus resulted in $7 \%, 6 \%$, and $17 \%$ removal of alumina, and $8 \%, 4 \%$, and $16 \%$ removal of silica, respectively. Bacillus polymyxa, Bacillus sphaericus, and Pseudomonas putida ensured silica removal percentage of $10.6 \%, 5.3 \%$, and $20 \%$, respectively. Aspergillus flavus and Pseudomonas putida were most efficient among all the bacterial and fungal strains used, ensuring an increase in iron content of about 3\% at the end of 10 days leaching [78].

Ronini [79] reported that heterotrophic organisms can be used to leach out the alumina and silica from the slimes generated by Tata Iron and Steel Company in India. He investigated the feasibility of Bacillus to leach the slimes and increase its iron content. At $\mathrm{pH} 7$, leaching for 5 days, at inoculums size of $20 \%$, Ronini obtained an optimum recovery of $79 \%$ of the iron content in the slimes.

\section{Biosurface Modification}

Adhesion of microorganisms to mineral surfaces is known to alter the hydrophobicity of minerals. It has been demonstrated that Acidithiobacillus ferrooxidans is suitable for the rapid treatment of sulfide ores where leaching is not the desired outcome. Surface treatment of sulfide minerals with bacterial solution is shown to influence their superficial chemical properties, thus altering their response in processes such as froth flotation and/or selective flocculation. This technique is being evaluated as a method of enhancing the physical separation of pyrite from coal in fine coal flotation circuits and is suggested as an alternative method to the total leaching of pyrite from coal $[80,81]$. In this technique the coal pulp is conditioned with Acidithiobacillus ferrooxidans bacteria for about 30 minutes and thus renders pyrite surface to be hydrophilic. This, in turn, enhances the selective flotation of coal from pyrite. Table 1 shows typical results of a study concerning bacterial leaching versus bacterial conditioning followed by flotation of minus 28 mesh coal containing $2.88 \%$ pyritic sulfur [69].

In a study concerning the effect of bacterial conditioning of sphalerite and galena, it was found that the floatability of galena decreased markedly (Figure 4) due to oxidation of 
TABLE 1: Flotation, bacteria leaching, and combinations of bacterial conditioning and flotation of -28 mesh coal containing $2.88 \%$ pyritic sulfur $[69]^{*}$.

\begin{tabular}{lccccc}
\hline \multirow{2}{*}{ Process } & \multicolumn{3}{c}{ Coal product specifications } \\
& Coal yield, \% & $\begin{array}{c}\text { Pyritic sulfur, } \\
\%\end{array}$ & $\begin{array}{c}\text { Pyritic sulfur } \\
\text { removal, \% }\end{array}$ & $\begin{array}{c}\text { Ash, \% } \\
\text { value, kcal/kg }\end{array}$ \\
\hline Regular conditioning and one-stage flotation & 73.74 & 1.29 & 66.76 & 22.5 & - \\
Bacterial leaching (10 days leaching) & 100 & 1.42 & 56.6 & 30.47 & 5260 \\
Bacterial conditioning (4 hours) and one stage flotation & 78.0 & 0.825 & 77.63 & 18.5 & 6361 \\
Bacterial conditioning (4 hours) and 3-stage flotation & 34.36 & 0.68 & 91.78 & 12.03 & - \\
\hline
\end{tabular}

${ }^{*} \mathrm{pH}=2.0$ for flotation conditioning and for bacterial leaching, and $\mathrm{pH}=9$ for all flotation stages.

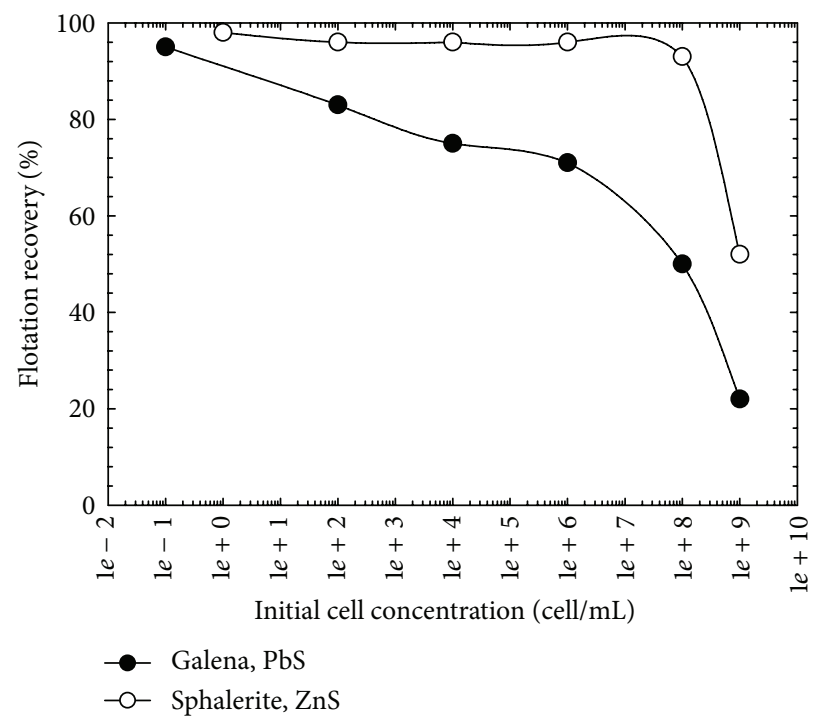

Figure 4: Effect of initial cell concentration during bacterial conditioning on the floatability of galena and sphalerite [82].

sulfur to insoluble lead sulfate species on the surface $[82,83]$. In the case of sphalerite (Figure 4) such effects were not observed since the zinc sulfate formed is soluble. The reported results have significant implications to the selective flotation of lead-zinc sulfides.

Recently, a copper concentrate assaying $22.23 \% \mathrm{Cu}$ was obtained through bacterial conditioning followed by flotation, whereas a copper concentrate assaying $18.20 \% \mathrm{Cu}$ was obtained in conventional flotation [84]. This means that the copper grade of the flotation concentrate, subjected to bacterial conditioning, is higher by $22 \%$ than the concentrate obtained by conventional flotation without bacterial conditioning. Acidithiobacillus ferrooxidans can affect mineral surfaces by direct (intimate) contact or indirect (no intimate) contact mechanisms. In both cases, the bacteria eliminate the occurrence of oxidized sulfur which (the sulfur) has hydrophobic properties and induces higher floatability to minerals so that hydrophobicity of pyrite is decreased [85].

According to the mechanisms explained above, bacteria are more effective on the pyrite surface than on the chalcopyrite surface. This is because at low $\mathrm{pH}$ values, the oxidation of pyrite is more pronounced than that of chalcopyrite. In addition, Acidithiobacillus ferrooxidans increases the oxidation rate of pyrite gradually. Under these conditions, the formation of jarosite layer takes place at lower $\mathrm{pH}$ values. Once jarosite is formed, it precipitates on mineral surfaces and decreases the effectiveness of reagent/mineral surface interaction in flotation resulting in pyrite depression. From the above discussion, it could be conclude that Acidithiobacillus ferrooxidans appears to play a dual role, promoting flotation under certain conditions while enhancing depression of minerals under some other conditions. Promotion of floatability of sulphide minerals in the presence of this type of bacteria could be understood in the light of elemental sulphur formation on mineral surfaces through biooxidation. Bacterial interaction for prolonged periods of time leads to reoxidation of the sulphur to sulphoxy compounds and ultimately to sulphate. Gradual build-up of such oxidized layers on mineral surfaces would impede flotation.

\section{Bacteria Activities in Flotation and Flocculation}

There is high evidence that microorganisms could be used to flocculate finely divided minerals and/or other solids suspensions [86, 87]. It was found that the bacterium, Mycobacterium phlei, has a demonstrated potential to be used for the flotation of hematite, Figure 5. The decrease in flotation recovery at high bacteria concentration $(>20 \mathrm{ppm})$ was due to the formation of hematite aggregates too large to be levitated by air bubbles [88]. This same type of bacterium proved to be successful in flocculating a variety of finely divided minerals such as hematite (Figure 6), phosphate slimes (Figure 7), and coal (Figure 8) [86, 87, 89]. Figure 6 shows that the concentration of bacteria cells affects the extent of flocculation. This type of bacterium, Mycobacterium Phlei, possesses highly negative features on highly hydrophobic surfaces. It was suggested that these properties arise in large part from its fatty acid surface [88]. Because of these characteristics, the organism which is readily adsorbed onto the hydrophilic surface of the mineral may have a negative, neutral, or low positive charge. It also adheres to many hydrophobic minerals due to the created adhesion (attraction) energy of hydrophobic interactions [90].

Interaction between Paenibacillus polymyxa with minerals such as hematite, corundum, calcite, kaolinite, and 


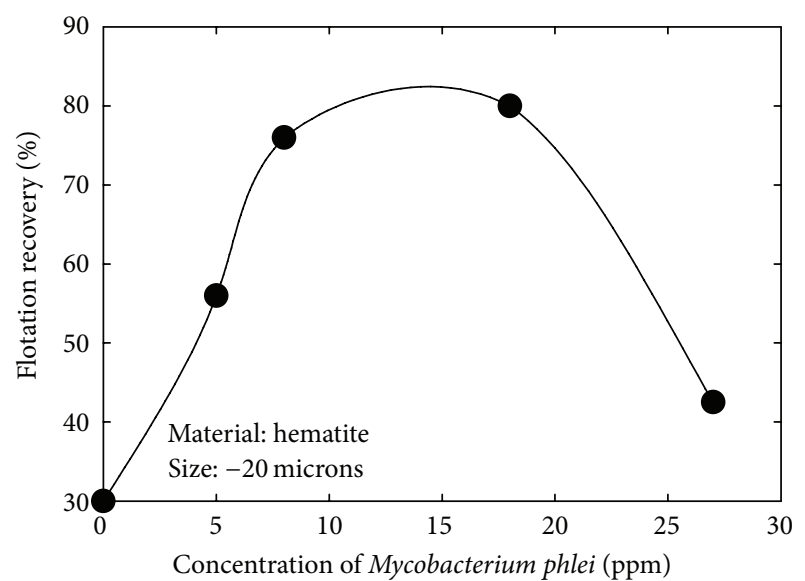

FIGURE 5: Hallimond tube flotation recovery of hematite as a function of Mycobacterium phlei concentration (operating conditions: $\mathrm{pH}=5 ; 1$ gram of hematite; 10 min flotation) [88].

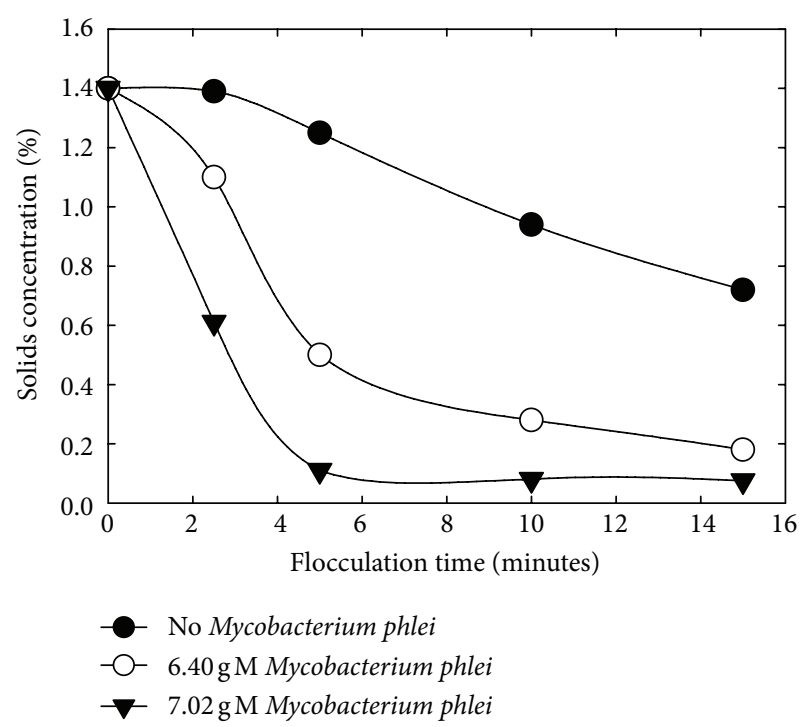

FIgURE 6: Flocculation of hematite slimes with and without Mycobacterium phlei as a function of time. Samples were collected at $4 \mathrm{~cm}$ from the bottom surface of a $1000 \mathrm{~mL}$ graduated cylinder [88].

quartz resulted in significant surface-chemical changes. Quartz and kaolinite were rendered more hydrophobic, while hematite, calcite, and corundum became more hydrophilic after biotreatment. Through biotreatment of the above minerals, it was possible to selectively separate silica and alumina from iron minerals either by flotation or selective flocculation [91].

Utilization of microorganisms and associated extracellular metabolic products in selective flotation and flocculation has been recently reported [91-93]. Patra and Natarajan [94] showed that different protein fractions derived from Paenibacillus polymyxa exhibited varying surface adsorption capacity towards minerals such as quartz, pyrite, chalcopyrite, galena, and sphalerite. Proper use of fractionated protein groups rendered pyrite and chalcopyrite hydrophilic, while

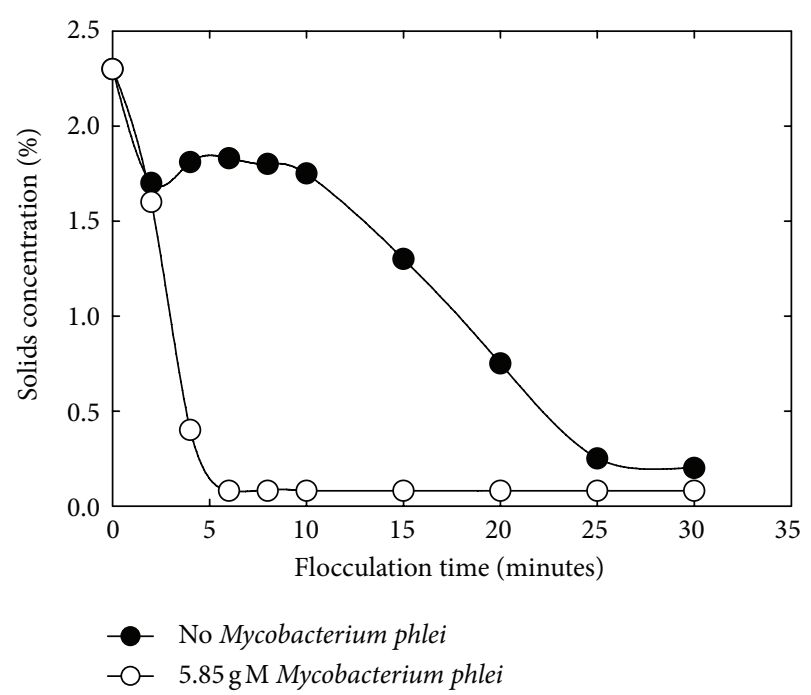

Figure 7: Flocculation of a 1.4\% suspension of Four Corners (Florida) phosphate slime with the addition of two different concentrations of Mycobacterium phlei [88].

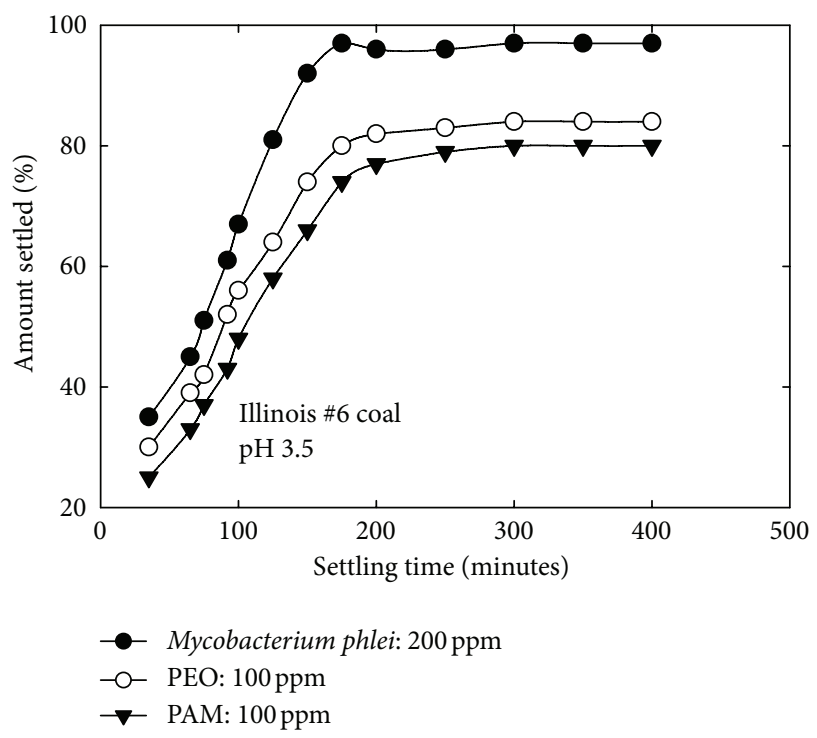

FIgURE 8: Amount of coal settled as a function of time in the presence of different flocculants: Mycobacterium phlei, Polyacrylamide flocculent (PAM), and Polyethylene Oxide flocculent (PEO) [89].

sphalerite, galena and quartz exhibited enhanced surface hydrophobicity after bio-treatment. Similarly, prior protein treatment resulted in selective flocculation of pyrite and chalcopyrite together, while galena, sphalerite, and quartz were effectively dispersed. These studies demonstrated that bacterial proteins could effectively replace the conventional amine and xanthate types of collectors which are toxic and expensive.

Due to the adherence of bacteria to mineral surfaces, some strains can be used to modify mineral surfaces to aid selective recovery of valuable minerals in flotation or flocculation processes. Some bacteria can selectively depress 
TABLE 2: Flotation recovery of minerals treated individually, in presence and in absence of collector without cells or extract and after interaction with mineral-grown cells and cell-free extract [70].

Flotation recovery, percent

\begin{tabular}{lcccc}
$\begin{array}{l}\text { Mineral }(-105+75 \\
\text { microns })\end{array}$ & \multicolumn{2}{c}{ Without cells or cell-free extract } & \multicolumn{2}{c}{ With cells or cell-free extract } \\
& Without collector & With collector & $\begin{array}{c}\text { After interaction } \\
\text { with cells }(1 \mathrm{~h})\end{array}$ & $\begin{array}{l}\text { After interaction with } \\
\text { cells-free extract }(1 \mathrm{~h})\end{array}$ \\
\hline Quartz & 14.6 & 97.8 & 91.5 & 90.1 \\
Calcite & 12.5 & 95.0 & 74 & 50.0 \\
Corundum & 11.0 & 96.0 & 73.2 & 30.0 \\
Hematite & 11.0 & 95.0 & 4.8 & 14 \\
\hline
\end{tabular}

the flotation of one mineral compared to another. The depression can either result from bacteria oxidizing or otherwise modifying the surface of the mineral to render it less floatable or prevent the subsequent adsorption of a flotation collector. Due to the adherence of bacteria to mineral surfaces, some strains can be used to modify mineral surfaces to aid selective recovery of valuable minerals in flotation or flocculation processes. Some bacteria can selectively depress the flotation of one mineral compared to others. The depression can either result from bacteria oxidizing or otherwise modifying the surface of the mineral to render it less floatable or from bacteria adhering to the mineral preventing the subsequent adsorption of a flotation collector.

Adhesion of Bacillus subtilis and Mycobacterium phlei onto dolomite and apatite was studied by sorption measurements and scanning electron microscopy [95]. It was found that both Bacillus subtilis and Mycobacterium phlei adhere onto dolomite surface more readily than onto apatite surface at acidic and near neutral $\mathrm{pH}$ values. At more basic $\mathrm{pH}$ values Bacillus subtilis adheres more readily onto the mineral surface and remains a better depressant for dolomite than for apatite. However, Mycobacterium phlei, at basic $\mathrm{pH}$ values, adsorbs more onto apatite than onto dolomite acting as a weaker depressant for dolomite and a stronger depressant for apatite compared with Bacillus subtilis. The differences in adsorption characteristics were attributed to differences in surface properties of the two bacteria species and of the two minerals. The net result of the study indicated that, while both bacteria function as depressants in anionic collector flotation of dolomitic phosphate ores, Bacillus subtilis functions as the stronger depressant, especially for dolomite [95].

In a more recent investigation, Sarvamangala and Natarajan [70] showed that the microorganism Bacillus subtilis and the extracellular protein have been utilized for the separation of hematite from the other oxide minerals. It is evident from the obtained results that the presence of bacterial cells and cell-free extract promoted the flocculation and settling of hematite whereas in the case of quartz, corundum, and calcite the interaction with bacterial cells and cell-free extract favored more dispersion of the minerals. Flotation behavior of hematite-quartz and calcite-corundum systems was studied before and after interaction with bacterial cell-free extract and bacterial cells. The obtained results, Table 2 [70], indicate that interaction with Bacillus subtilis confers surface hydrophobicity on quartz, calcite, and corundum, while similar biotreatment renders hematite more hydrophilic. Relative hydrophobicity or hydrophilicity of mineral-grown bacterial cells depends on the ratio of proteins and polysaccharides present on the cell walls. Bacterial cell population and their interaction period with minerals, as well as mineral surface coverage through bacterial adhesion control the mineral surface hydrophobicity regarding flotation and/or flocculation. These studies open a wide venue for possible developments of biotechnological applications for environmentally safe mineral beneficiation operations. However, more detailed investigations need to be carried out to make a clear insight into the control of bacterial cell wall composition. Also, the mechanisms of bacteria-mineral surfaces interactions should be clearly highlighted.

In 2011, Reyes-Bozo et al. [96] studied the effect of biosolids (obtained from waste water treatment plant, Chile) on hydrophobic properties of sulfide ores on a laboratory scale. The principal components of biosolids are humic substances, mainly humic acid, and phosphorus compounds. The interaction between the mineral surface and the functional groups found in biosolids, as a collector, for copper sulfide ores, was investigated through zeta potential measurements, FT-IR analysis, and film flotation tests. The results showed that biosolids change the hydrophobicity of the sulfide minerals by adsorbing onto the surface. Biosolids show greater affinity for pyrite while commercial humic acid shows similar behavior to industrial collectors. Therefore, both biosolids and humic acids can change the hydrophobic properties of sulfide ores and can be used as collectors in froth flotation processes. Thus, the use of biosolids is feasible in a preliminary flotation stage for removing pyrite or in the rougher stage of froth flotation to separate important sulfide minerals from the gangue.

\section{Bioremediation}

In addition to being useful in the mineral beneficiation area, recent developments in biotechnology have given promises that biotechnology may also provide means for bioremediation of environmental problems generated in the mineral, metallurgical, and chemical industries. For example, in the flotation of wastes, an investigation concerning the biodegradation of thiol collectors by the bacterium Pseudomonas fluorescents was reported [88]. In this study it was indicated that a residual xanthate concentration of $0.12 \mathrm{mg} / \mathrm{L}$ in the wastewater from a lead concentrator was completely destroyed in 


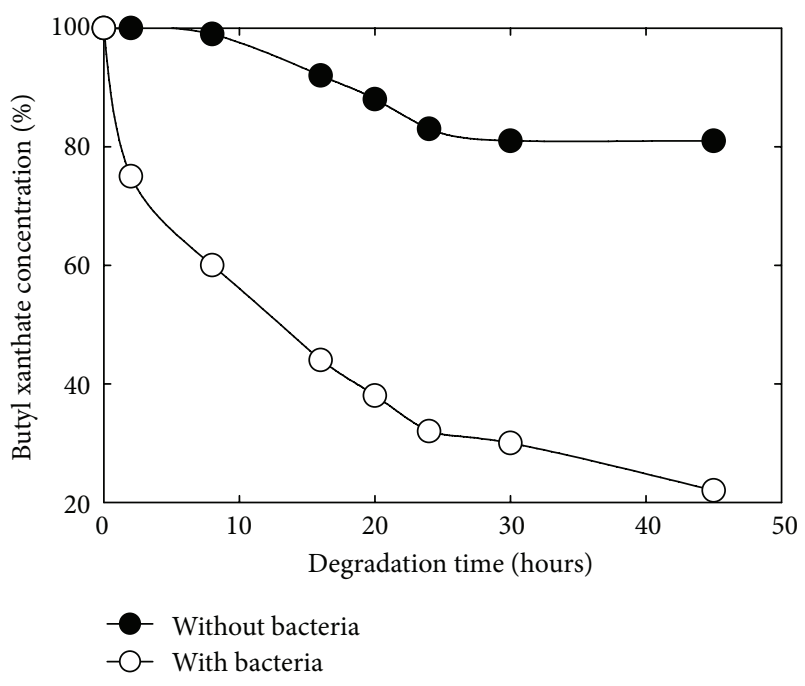

Figure 9: Influence of Pseudomonas fluorescens on the degradation of butyl xanthate [88].

five minutes after treatment with a bacterial suspension. Butyl xanthate destruction by Pseudomonas fluorescents has also been investigated, and typical results are shown in Figure 9. In this figure, it is clear that the concentration of butyl xanthate was decreased by about $20 \%$ of its original concentration in 40 minutes in the presence of bacteria [88].

Concerning polluted soil bioremediation, there is an excellent review, in which sources of soil pollution, bioremediation strategies, and the direction of further research have been highlighted [97]. It is known that, under specified conditions, certain microorganisms or enzymes derived from microorganisms are able to break down cyanides, and hence, there is a potential for using these organisms in bioremediation cyanide wastes discharged from precious metal hydrometallurgical plants [98]. Noel et al. [24] cultivated bacterial strains from solids previously exposed to cyanide solution which tolerate $300 \mathrm{ppm}$ sodium cyanide under anaerobic conditions. In the selected soil samples, these bacteria reduced the level of cyanide from approximately $300 \mathrm{ppm}$ to essentially zero in about 50 days under anaerobic conditions. Typical results of these experiments are shown in Figure 10. In this study, various nutrient media were investigated and the maximal growth of bacteria was established at Medium A, which was composed of $1.0 \mathrm{~g} / \mathrm{L} \mathrm{K}_{2} \mathrm{HPO}_{4}$, $0.2 \mathrm{~g} / \mathrm{L} \mathrm{MgSO}_{4} \cdot 7 \mathrm{H}_{2} \mathrm{O}, 2 \mathrm{~g} / \mathrm{L} \mathrm{FeSO}_{4}, 2 \mathrm{~g} / \mathrm{L} \mathrm{MnCl}_{12} \cdot 4 \mathrm{H}_{2} \mathrm{O}$, and $0.001 \mathrm{~g} / \mathrm{L} \mathrm{Na}_{2} \mathrm{MoO}_{4} \cdot 2 \mathrm{H}_{2} \mathrm{O}$.

Maniatis et al. [99] demonstrated that biological destruction of cyanide in mining water was effective in the laboratory and in the field. In this study, the cyanide was put in a complex form with selenium by aerobic reactor which was run continuously for six days to remove cyanide and then run one more time through a series of anaerobic reactors to remove selenium. The aerobic reactor removed $95 \%$ of the cyanide content in the first 24 hours with another $3 \%$ removal over the next five days. No nutrient addition was required.

Biosorption laboratory research activities are expected to reach industrial application for the detoxication of industrial waste water $[100,101]$. Considerable interest exists in the

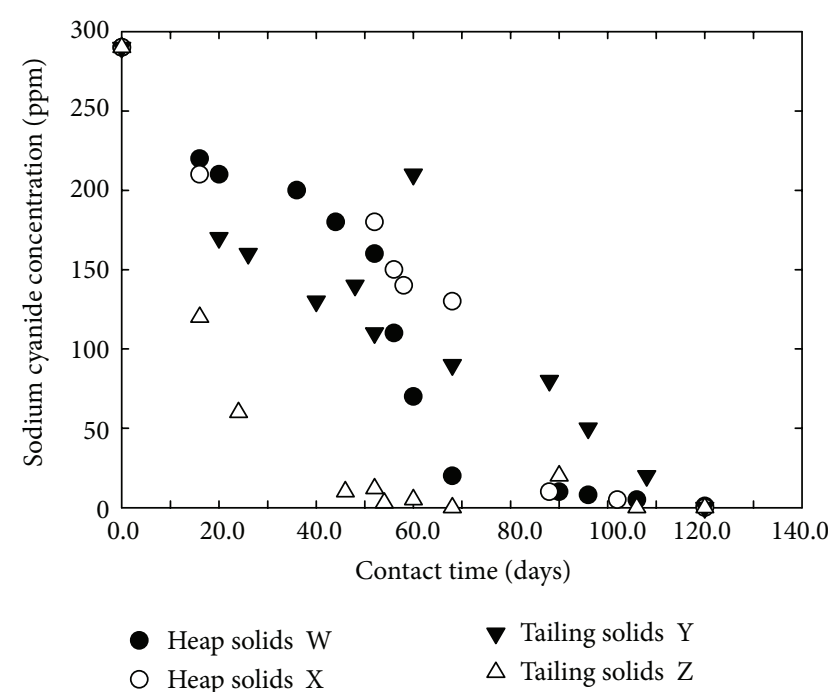

FIGURE 10: Variation of sodium cyanide concentration as a function of inoculum solids and contact time in the presence of nutrient Medium A at locations W, X, Y, and Z [24].

application of biosorption to the removal of a number of environmental contaminants including toxic heavy metals such as chromium [102], selenium [103], and cadmium, as well as radionuclides such as uranium [104].

Chaalal et al. [105] reported the use of thermophilic bacteria (belongs to Bacillus family) for the removal of lead compounds contaminating the drinking water. These bacteria were isolated and used in a reactor coupled with a membrane system. The bacteria, the stirrer, and the membrane housed in the reactor were arranged in a distinctive way to form the novel biostabilization process proposed in this research. They claimed that the proposed technique could be used at low cost and with great confidence in purifying drinking water. The system was found to be adequate for remediating drinking water having lead concentration up to $40 \mathrm{ppm}$. At the end of the operation, the lead concentration reaches the level allowed by the world health organization regulations.

Bioremediation of waters contaminated with crude oil and toxic heavy metals was also achieved by the process of microbial dissimilatory sulfate reduction and biosorption [106].

\section{Summary}

The present paper highlights a number of new possibilities for industrial application of biotechnological principles for the extraction of metal values from inorganic resources. The present industrial interest in bioleaching methods is motivated by the fact that these processes can produce metal values from low-grade resources for approximately one-third to one-half of the cost of the conventional smelting techniques without polluting the environment. Furthermore, selective implementation of living systems can offer opportunities for reduced labor, increased productivity, and technological advances. In fact, bacteria technologies have been applied on a commercial scale for the recovery of copper and uranium from low-grade ores and industrial wastes. 
Bacterial activities have been recently introduced in the mineral processing technology. They have been used in mineral surface modification, flocculation, and collectors in flotation. In these areas, parameter optimization and process control are required for efficient application. In addition, higher levels for scaling up the operations must be encouraged in all biomineral processing systems for industrial purpose. Also, detailed understanding of the biosurfactant role in modifying the mineral surfaces and exploring bioflotation applications is currently lacking.

Bacterial leaching is a new development in hydrometallurgy of metal sulphides. Greater understanding of the basic mechanisms of bacterial mineral leaching is still required which hinders the controlled utilization of this technology. Published information relating to the oxidation of various minerals differs greatly and sometimes contradicts each other, with respect to the acting mechanisms, the rate, and amount of oxidation took place under specific conditions. This would indicate that considerable information is still necessary to determine the most efficient types of bacteria, proper operating conditions, manner in which they should be cultivated, and the mechanisms with which they attach to the minerals to be leached.

Microbiological leaching is influenced by a number of parameters, and it functions best if carried out at optimum leaching conditions. Intensive aeration is required to assure maximum oxygen mass transfer into the leach solution. The smallest particle size of the solid sulphide substrate will assure the highest rate and yield of metal extraction. The Eh must be kept below $500 \mathrm{mV}$ in order to avoid jarosite type and basic ferric hydroxide precipitation on the surface of the solid substrate. In all leaching techniques, wherever possible, a cyclic leaching process should be applied.

It seems that new trends are evolving as the knowledge of bacterial activity relative to industrial applications is furthered. Biohydrometallurgical applications are multidisciplinary in nature, and should be dealt with at optimum conditions for optimal effects. Bioremediated processes are of high importance, especially in copper, uranium, and precious metals industries. However, their applicability in the remediation of contaminated soils and industrial aqueous effluents is hampered by lack of sufficient information.

\section{References}

[1] Q. P. Granger, "Bacterial leaching of minerals," Colliery Guardian Redhill, vol. 232, no. 6, pp. 212-214, 1984.

[2] F. D. Pooley, "The role of biohydrometallurgy in mineral processing," in Innovations in Mineral and Coal Processing, S. Atak, G. Onal, and M. S. Celik, Eds., p. 435, Balkema, Rotterdam, The Netherlands, 1998.

[3] A. S. S. Seifelnassr and A. Z. M. Abouzeid, "New trends in mineral processing: exploitation of bacterial activities," The Journal of Mineral Processing, vol. 3, no. 4, p. 17, 2000.

[4] A. W. Hudson and G. D. Vanasdale, "Heap leaching at Bisbee, Arizona," Transactions of the Society of Mining, vol. 64, p. 137, 1923.

[5] A. Bruynesteyn and R. P. Hack, "The biotank leach process for the treatment of refractory gold/silver concentrates," in
Microbiological Effects on Metallurgical Processes, J. A. Clum and L. A. Haas, Eds., pp. 121-128, Tms-AIME, New York, NY, USA, 1985.

[6] J. Murpby, E. Ristenberg, D. Marek, R. Moble, B. Beck, and D. Skidmore, "Microbial dessulphurization of coal by Thermophilic bacteria," in Microbiological Effects on Metallurgical Processes, J. A. Clum and L. A. Haas, Eds., pp. 99-110, TMS, 1985.

[7] J. E. Moss and J. E. Anderson, "The effect of environment on bacterial leaching rates," Proceedings of the Australasian Institute of Mining and Metallurgy, vol. 225, p. 15, 1968.

[8] M. Makintosh, "Nitrogen fixation by T. ferrooxidans," Journal of General Microbiology, vol. 70, p. 66, 1971.

[9] A. E. Torma, "The role of Thiobacillus ferrooxidans in hydrometallurgical processes," Advances in Biochemical Engineering, vol. 6, pp. 1-37, 1977.

[10] M. P. Silverman, "Mechanism of bacterial pyrite oxidation," Journal of Bacteriology, vol. 94, no. 4, pp. 1046-1051, 1967.

[11] M. P. Silverman and D. G. Lundgren, "Studies on the chemoautotrophic iron bacterium ferroobacillus ferrooxidans an improved medium and harvesting procedure for securing high cell yields," Journal of Bacteriology, vol. 77, pp. 642-647, 1959.

[12] F. D. Pooley, "Mineral leaching with bacteria," in Environmental Biotechnology, F. F. Christopher and D. A. John, Eds., pp. 114134, Ellis Horwood, John Wiley and Sons, New York, NY, USA, 1987.

[13] C. L. Brierley and J. A. Brierley, "A chemoautotrophic and thermophilic microorganism isolated from an acid hot spring," Canadian Journal of Microbiology, vol. 19, no. 2, pp. 183-188, 1973.

[14] G. Millonig, M. De Rosa, A. Gambacorta, and J. D. Bu’lock, "Ultrastructure of an extremely thermophilic acidophilic micro organism," Journal of General Microbiology, vol. 86, no. 1, pp. 165-173, 1975.

[15] V. I. Groudeva, S. N. Grouder, and M. I. markov, "A comparison between Thermophilic bacterial with respect to their ability to leach sulfide minerals," in Fundamental and Applied Biohydrometallurgy, R. W. Lawrence, R. M. Brauion, and H. G. Ebener, Eds., p. 484, Elsevier, 1986.

[16] A. E. Torma, "Biohydrometallurgy as an emerging technology," in Proceedings of the Biotechnology and Bioengineering Symposium No. 16, p. 49, 1986.

[17] M. L. Free, T. Oolman, S. Nagpal, and D. A. Bahlstrom, "Bioleaching of sulfide ores-distinguishing between indirect and direct mechanisms," in Mineral Bioprocessing, R. W. Smith and M. A. Misra, Eds., p. 485, TMS, 1991.

[18] Y. R. K. Mirajkar, K. A. Natarajan, and P. Somasundaran, "Growth and attachment of Thiobacillus ferrooxidans during sulfide mineral leaching," International Journal of Mineral Processing, vol. 50, no. 3, pp. 203-210, 1997.

[19] G. S. Hansford, "Studies on the mechanisms and kinetics of bioleaching," Fizykochemiczne Problemy Mrtalugil, vol. 32, pp. 281-291, 1998.

[20] D. Mishra and Y. Rhee, "Current research trends of microbiological leaching for metal recovery from industrial wastes," in Current Research, Technology, Education Topics in Applied Microbiology and Microbial Biotechnology, A. Mendez-Vilas, Ed., FORMATEX, 2010.

[21] A. R. Colmer and M. E. Hinkle, "The role of microorganisms in acid mine drainage: a preliminary report," Science, vol. 106, no. 2751, pp. 253-256, 1947. 
[22] W. R. Ruzzel and P. C. Trussel, "Isolation and properities of an iron oxidizing Thiobacillus," Journal of Bacteriology, vol. 85, p. 595, 1963.

[23] K. A. Natarajan and I. Iwasaki, "Microbe/mineral interaction in leaching of complex sulfides," in Microbiological Effects on Metallurgical Processes, S. A. Clum and L. A. Hass, Eds., p. 113, Tms-AIME, New York, NY, USA, 1985.

[24] D. M. Noel, M. C. Fuerstenau, and J. L. Hendrix, "Degradation of cyanide utilizing facultative anaerobic bacteria," in Mineral Bioprocessing, R. W. Smith and M. Misra, Eds., pp. 355-366, TMS, 1991.

[25] W. E. Ruzzel, "Bacterial leaching of metallic sulfides," Canadian Institute of Mining, vol. 55, p. 190, 1962.

[26] N. Lazaroff, "Sulfate requirement for iron oxidation to enhance gold and silver recovery from pyritc ores and concentrates," CIM Bulletin, vol. 85, p. 78, 1963.

[27] A. H. Tuovimen and D. P. Kelly, "Studies on the growth of Thiobacillus ferrooxidans," Archives of Microbiology, vol. 88, p. $285,1973$.

[28] I. J. Corrans, B. Harris, and B. J. Ralph, "Bacterial leaching: an introduction to its application and theory and a study on its mechanisms of operation," Journal of the South African Institute of Mining and Metallurgy, vol. 72, p. 221, 1972.

[29] A. Pinches, "Bacterial leaching of an arsenic-bearing sulfide concentrate," in Leaching and Reduction in Hydromrtallurgy, A. R. Burkin, Ed., p. 28, IMM, London, UK, 1975.

[30] H. Sakaguchi and M. Silver, "Microbiological leaching of a chalcopyrite concentrate by Thiobacillus ferrooxidans," Biotechnology and Bioengineering, vol. 18, no. 8, pp. 1091-1101, 1976.

[31] A. E. Torma, C. C. Walden, and R. M. Branion, "Microbiological leaching of a zinc sulfide concentrate," Biotechnology and Bioengineering, vol. 12, no. 4, pp. 501-517, 1970.

[32] C. L. Brierley, "Bacterial leaching," CRC Critical Reviews in Microbiology, vol. 6, no. 3, pp. 207-206, 1978.

[33] R. L. Braun and R. G. Mallon, “Combined leach-circulation calculation for predicting in-situ copper leaching of primary sulfide ore," Transactions of the Society of Mining Engineers AIME, vol. 258, no. 2, pp. 103-110, 1975.

[34] P. R. Norris, L. Parrott, and R. M. Marsh, "Moderately Thermophilic mineral-oxidizing bacteria," in Proceedings of the Biotechnology and Bioengineering Symposium No. 16, H. L. Ehrlich and D. S. Holmes, Eds., pp. 253-363, John Wiley and Sons, 1986.

[35] H. Kandemnir, "Fate of sulfide Sulfur bacterial oxidation of sulfide minerals," in Microbiological Effects on Metallurgical Processes, J. A. Clum and L. A. Haas, Eds., p. 51, TMS, 1985.

[36] M. Elzeky and Y. A. Attia, "Effect of bacterial adaptation on kinetics and mechanisms of bioleaching ferrous sulfides," Chemical Engineering Journal and the Biochemical Engineering Journal, vol. 56, no. 2, pp. B115-B124, 1995.

[37] E. Peters, "Thermodynamic and kinetic factors in the leaching in sulfide minerals from ore deposits and dumps," SME Short Course in Bio Extractive Mining, SME/AIME, 1970.

[38] A. Bruynesteyn and J. R. Copper, "Leaching of Canadian ore in test deposits," in Proceedings of the Solution Mining Symposium, F. F. Aplon and W. A. Mchinezy, Eds., p. 268, 1974.

[39] A. A. S. Seifelnassr, Bacterial aided percolation leaching of copper sulfide ores [Ph.D. thesis], University of Wales, Cardiff, UK, 1988.

[40] A. A. S. Seifelnassr and F. D. Pooley, "Biologically assisted ferric ion leaching of refractory copper sulfide ore," in Proceedings of the V111 International Mineral Processing Symposium, Antalya, Turkey, October 2000.
[41] J. A. Brierley and C. L. Brierley, "Microbial leaching of copper at ambient and elevated temperatures," in Metallurgical Applications of Bacterial Leaching and Related Microbiological Phenomenena, L. E. Murr, A. E. Torma, and J. A. Brierley, Eds., pp. 477-489, Academic Press, London, UK, 1978.

[42] L. E. Murr, A. E. Torma, and J. A. Brieley, Metallurgical Applications of Bacterial Leaching and Related Microbiological Phenomena, Academic Press, New York, NY, USA, 1978.

[43] H. M. Tsuchiya, "Microbial leaching of Cu-Ni sulfide concentrate," in Metallurgical Application of Bacterial Leaching and Related Microbiological Phenonena, L. E. Murr, A. E. Torma, and J. A. Brierley, Eds., pp. 365-372, Academic Press, London, UK, 1978.

[44] M. Gericke, A. Pinches, and J. V. Van Rooyen, "Bioleaching of a chalcopyrite concentrate using an extremely thermophilic culture," International Journal of Mineral Processing, vol. 62, no. 1-4, pp. 243-255, 2001.

[45] A. Sissing and S. T. L. Harrison, "Thermophilic mineral bioleaching performance: a compromise between maximizing mineral loading and maximizing microbial growth and activity," Journal of The South African Institute of Mining and Metallurgy, vol. 103, no. 2, pp. 139-142, 2003.

[46] J. Vilcáez, K. Suto, and C. Inoue, "Bioleaching of chalcopyrite with thermophiles: temperature-pH-ORP dependence," International Journal of Mineral Processing, vol. 88, no. 1-2, pp. 37-44, 2008.

[47] J.-L. Xia, Y. Yang, H. He et al., "Investigation of the sulfur speciation during chalcopyrite leaching by moderate thermophile Sulfobacillus thermosulfidooxidans," International Journal of Mineral Processing, vol. 94, no. 1-2, pp. 52-57, 2010.

[48] A. Behrad Vakylabad, "A comparison of bioleaching ability of mesophilic and moderately thermophilic culture on copper bioleaching from flotation concentrate and smelter dust," International Journal of Mineral Processing, vol. 101, no. 1-4, pp. 9499, 2011.

[49] W. A. Gow and G. M. Ritcey, "Treatment of canadian uranium ores," Canadian Mining and Metallurgical Bulletin, vol. 62, no. 692, pp. 1330-1339, 1969.

[50] R. Guay, A. E. Torma, and M. Silver, "Ferrous ion oxidation and uranium solubilization from a lowgrade ore by "Thiobacillus ferrooxidans'”' Annales de Microbiologie, vol. 126, no. 2, pp. 209219, 1975.

[51] A. E. Torma, C. C. Walden, D. W. Duncan, and M. R. Brauion, "Effect of carbon dioxide and particle surface area on the micro biological leaching of a zinc sulfide concenytates," Biotechnology and Bioengineering, vol. 14, p. 777, 1992.

[52] A. E. Torma and K. N. Subramanian, "Selective bacterial leaching of a lead sulphide concentrate," International Journal of Mineral Processing, vol. 1, no. 2, pp. 125-134, 1974.

[53] Y. Attia, L. Tchfield, and L. Vaaler, "Application of biotechnology in the recovery of gold," in Microbiological Effects on Metallurgical Processes, J. A. Clum and L. A. Haas, Eds., pp. 11-20, Tms-AIME, New York, NY, USA, 1985.

[54] E. Livesey, P. Norman, and R. Livesey, "Gold recovery from arsenopyrite/pyrite ore by bacterial leaching and cyanidation," in Recent Progress in Biohydrometallurgy, pp. 627-641, Associzione Mineraria Sarda, Iglesias, Italy, 1983.

[55] E. Livesey, "Bacterial leaching of gold, uranium, pyrite-bearingcompacted mine tailing slimes," in Fundamental and Applied Biouhydro Metallurgy, R. W. Lawrnce, R. M. Braniou, and H. G. Ebmer, Eds., pp. 89-97, Elsevier, 1986. 
[56] H. L. Ehrlich, "Bacterial leaching of silver from a silver containing mixed Sulfide ore by a continuous process," in Fundamental and Applied Biohydrometallurgy, R. W. Lawrence, R. M. Braniou, and H. G. Ebmer, Eds., pp. 77-88, Elsevier, 1986.

[57] R. W. Lawrence and A. Bruynesteyn, "Biological pre-oxidation to enhance gold and silver recovery from refractory pyritic ores and concentrates," CIM Bulletin, vol. 76, no. 857, pp. 107-110, 1983.

[58] D. S. Holmes and K. A. Debus, "Opportunities for biological metal recovery," in Mineral Bioprocessing, R. W. Smith and M. Misra, Eds., pp. 57-80, Tms-AIME, 1991.

[59] C. C. Towskey, I. S. Ross, and A. S. Atkins, "Biorecovery of metallic residues from various industrial effluents using filamentous Fungi," in Fundamental and Applied Biohydromrtallurgy, R. W. Lawrence, R. M. R. Branion, and H. G. Ebner, Eds., pp. 279-290, Elsevier, 1986.

[60] A. E. Torma, "Mineral bioprocessing," in BIOMIN, 93, pp. 110, Australian Mineral Foundation, Glenside, South Australia, 1993.

[61] S. N. Groder, I. I. Spasova, and I. M. Ivauov, "Microbial leaching of a gold-bearing pyrite Concentrate," in Changing Scopes in Mineral Processing, M. Kemal, V. Arslan, A. Askar, and M. Canbazolgu, Eds., pp. 583-586, Balkema, Rotterdam, The Netherlands, 1996.

[62] A. Ozkan, S. Aydogan, and U. Akdermir, "Bacterial leaching as a pre-treatment step for gold recovery from refractory ores," in Proceedings of the Physicochemical problems of Mineral Processing, vol. 32, pp. 173-182, Wroclaw, Poland, 1998.

[63] Z. Sadowski, T. Farbiszewska, and J. Farbiszewka-Bajar, "The role of microorganisms in pretreatment of gold-bearing ores," in Proceedings of the Physicochemical Problems of mineral Processing 35th Symposium, pp. 151-165, Wroclaw, Poland, 1998.

[64] S. Ubaldini, F. Veglió, L. Toro, and C. Abbruzzese, "Biooxidation of arsenopyrite to improve gold cyanidation: study of some parameters and comparison with grinding," International Journal of Mineral Processing, vol. 52, no. 1, pp. 65-80, 1997.

[65] D. Karamanev, A. Margaritis, and N. Chong, "The application of ore immobilization to the bioleaching of refractory gold concentrate," International Journal of Mineral Processing, vol. 62, no. 1-4, pp. 231-241, 2001.

[66] B. V. Mihaylov and J. L. Hendrix, "Biooxidation of a sulfide gold ore in columns," in Mineral Bioprocessing, R. W. Smith and M. Misra, Eds., p. 163, TMS-AIME, 1991.

[67] B. A. Paponetti, S. Ubaldini, C. Abbruzzese, and L. Tora, "Biometallurgy for the recovery of gold from arsenopyrite Ores," in Mineral Bioprocessing, R. W. Smith and M. Misra, Eds., p. 179, TMS, 1991.

[68] P. Miller and A. Brown, "Bacterial oxidation of refractory gold concentrates., in Advances in Gold Ore Processing, M. A. Adams, Ed., Elsevier, 2005.

[69] M. Z. Dogan and M. S. Cleik, "Latest developments in coal desulphurization by flotation and microbial beneficiation," in Proceedings of the 3rd Mining, Petroleum, and Metallurgical Conference, vol. 1, pp. 2-4, Faculty of Engineering, Cairo University, February 1992.

[70] H. Sarvamangala and K. A. Natarajan, "Microbially induced flotation of alumina, silica/calcite from haematite," International Journal of Mineral Processing, vol. 99, no. 1-4, pp. 70-77, 2011.

[71] T. Farbiszewska, "Intensity of the bacterial leaching process from mining brown coal waste," Physico-Chemical Problems of Mineral Processing, vol. 22, pp. 145-159, 1990.
[72] G. I. Karavviko, Z. A. Avakyan, L. V. Ogurtsova, and O. F. Safanova, "Microbiological processing of bauxite," in Proceedings of International Symposium on Biohydrometallurgy, J. Salley, R. G. L. McGready, and P. L. Wichlacz, Eds., pp. 93-102, Canmet, Ottawa, Canada, 1989.

[73] L. V. Ogurtsova, G. I. Karavaiko, Z. A. Avakyan, and A. A. Korenevsii, "Activity of various microorganisms in extracting elements from bauxite," Microbiology, vol. 58, pp. 774-780, 1990.

[74] S. S. Vasan, J. M. Modak, and K. A. Natarajan, "Some recent advances in the bioprocessing of bauxite," International Journal of Mineral Processing, vol. 62, no. 1-4, pp. 173-186, 2001.

[75] P. Anand, J. M. Modak, and K. A. Natarajan, "Biobeneficiation of bauxite using Bacillus polymyxa: calcium and iron removal," International Journal of Mineral Processing, vol. 48, no. 1-2, pp. 51-60, 1996.

[76] C. Cameselle, M. T. Ricart, M. J. Núñez, and J. M. Lema, "Iron removal from kaolin. Comparison between "in situ" and "twostage” bioleaching processes," Hydrometallurgy, vol. 68, no. 1-3, pp. 97-105, 2003.

[77] H. L. Ehrlich, "Past, present and future of biohydrometallurgy," Hydrometallurgy, vol. 59, no. 2-3, pp. 127-134, 2001.

[78] S. Shitarashmi, Biomineral processing: a suitable approach [M.S. thesis], National Institute of Technology, Rourkela, India, 2009.

[79] N. Ronini, Feasibility study on the microbial separation of iron ore slime [M.S. thesis], National Institute of Technology, Rourkela, India, 2011.

[80] G. F. Andrews, P. R. Dugan, and C. J. Stevens, "Combining physical and bacterial treatment for removing pyritic sulfur from coal," in Processing and Utilization of High Sulphur Coal IV, P. R. Dugan, D. R. Quigley, and Y. A. Attia, Eds., p. 515, Elsevier, 1991.

[81] Y. A. Attia, M. Elzekey, F. Bavariam, and L. S. Fan, "Cleaning, and desulphurization of high sulfur coal by selective flocculation and bioleaching in draft tube fluidized bed reactor," in Proceedings of the 3rd Mining, Petroleum, Metallurgy Conference, vol. 1, pp. 2-4, Faculty of Engineering, Cairo University, February 1992.

[82] M. K. Yelloji, K. A. Natarajan, and P. Somasundran, "Effect of bacterial conditioning of sphalerite and galena with Thiobacillus ferrooxidans on their floatability," in Mineral Bioprocessing, R. W. Smith and M. Misra, Eds., pp. 105-120, TMS, 1991.

[83] K. Hanumantha Rao, A. Javadi, T. Karlkvist, A. Patra, A. Vilinska, and I. V. Chernyshova, "Revisiting sulphide mineral (Bio) processing: a few priorities and directions," in Proceedings of the 15th Balkan Mineral Processing Congress, Sozopol, Bulgaria, June 2013.

[84] A. Ekrem Yüce, H. Mustafa Tarkan, and M. Zeki Doğan, "Effect of bacterial conditioning and the flotation of copper ore and concentrate," African Journal of Biotechnology, vol. 5, no. 5, pp. 448-452, 2006.

[85] L. C. Bryner, R. B. Walker, and R. Palmer, "Some factors influencing the biological oxidation of sulfide minerals," Transactions of AIME, vol. 238, pp. 56-62, 1967.

[86] M. Misra, S. Chen, and R. W. Smith, "Kerogen aggregation using a hydrophobic bacterium," in Mineral Bioprocessing, R. W. Smith and M. Misra, Eds., p. 133, TMS-AIME, 1991.

[87] M. Misra, R. W. Smith, and J. Dubel, "Bioflocculation of finely divided minerals," in Mineral Bioprocessing, R. W. Smith and M. Misra, Eds., p. 91, TMS-AIME, 1991.

[88] R. W. Smith and M. Misra, "Mineral bioprocessing-an overview," in Mineral Bioprocessing, W. R. Smith and M. Misra, Eds., pp. 3-26, TMS, 1991. 
[89] M. A. Raichur, M. Misra, and R. W. Smith, "The Potential for selective flocculation of coal from pyrite using a Hydrophic bacterium," in Mineral Processing, Recent Advances and Future Trends, S. P. Mehrotra and R. Shekhar, Eds., pp. 686-693, Allied, New Delhi, India, 1995.

[90] D. A. Elgillani, Class Notes in Surface Chemistry, Cairo University, Faculty of Engineering, Department of Mining, Petroleum, and Metallurgical Engineering, Giza, Egypt, 2008.

[91] K. A. Natarajan and N. Deo, "Role of bacterial interaction and bioreagents in iron ore flotation," International Journal of Mineral Processing, vol. 62, no. 1-4, pp. 143-157, 2001.

[92] D. Santhiya, S. Subramanian, K. A. Natarajan, H. Hanumantha Rao, and K. S. E. Forssberg, "Bio-modulation of galena and sphalerite surfaces using Thiobacillus thiooxidans," International Journal of Mineral Processing, vol. 62, no. 1-4, pp. 121-141, 2001.

[93] M. N. Chandraprabha, K. A. Natarajan, and P. Somasundaran, "Selective separation of pyrite from chalcopyrite and arsenopyrite by biomodulation using Acidithiobacillus ferrooxidans," International Journal of Mineral Processing, vol. 75, no. 1-2, pp. 113-122, 2005.

[94] P. Patra and K. A. Natarajan, "Role of mineral specific bacterial proteins in selective flocculation and flotation," International Journal of Mineral Processing, vol. 88, no. 1-2, pp. 53-58, 2008.

[95] X. Zheng, P. J. Arps, and R. W. Smith, "Adhesion of two bacteria onto dolomite and apatite: their effect on dolomite depression in anianic flotation," International Journal of Mineral Processing, vol. 62, no. 1-4, pp. 159-172, 2001.

[96] L. Reyes-Bozo, R. Herrera-Urbina, M. Escudey et al., "Role of biosolids on hydrophobic properties of sulfide ores," International Journal of Mineral Processing, vol. 100, no. 3-4, pp. 124129, 2011.

[97] S. Pal, A. K. Patra, S. K. Reza, W. Wildi, and J. Pote, "Use of bio-resources for bioremediation of soil pollution," Natural Resources, vol. 1, pp. 110-125, 2010.

[98] S. Copaescu, G. fodor, G. Bota, L. Popa, and A. Pescaru, "Possibilities of treatment of residual waters containing cyanide and its recovery in a cyanidation plant from regia autonoma a cupului deva," in Changing Scopes in Mineral Processing, M. Kemal, V. Arslan, A. Akar, and M. Canbozoglu, Eds., pp. 591598, Balkema, Rotterdam, The Netherlands, 1996.

[99] T. Maniatis, B. Wahlquist, and T. Pickett, "Biological cyanide destruction in mineral processing waters," in Proceedings of the SME Annual Meeting, pp. 879-880, Denver, February 2004.

[100] J. A. Brierley, C. L. Brierley, and G. M. Goyalc, "AMTBIOCLAM, a new waste water treatment and metal recovery technology," in Fundamental and Applied Biohydrometallurgy, R. W. Lawrence, R. M. R. Branion, and H. G. Ebner, Eds., pp. 291-304, Elsevier, 1986.

[101] T. Jeffers, C. R. Ferguson, and P. G. Bennett, "Biosorption of metal contaminants from acidic mine waters," in International Mineral Bioprocessing, R. W. Smith and M. Misra, Eds., p. 289, TMS, 1991.

[102] W. A. Apel and C. E. Turick, "Bio-remediation of hexavalent chromium by bacterial reduction," in Mineral Bio-Processing, R. Smith and M. Misra, Eds., p. 376, TMS-AIME, 1991.

[103] J. M. Barnes, E. B. McNew, J. K. Polman, J. H. McCune, and A. E. Torma, "Selenate reduction by pseudomonas stutzeri," in Mineral Bioprocessing, R. W. Smith and M. Misra, Eds., p. 367, TMS-AIME, 1991.
[104] M. L. Apel, J. M. Barnes, and A. E. Torma, "Biosorption kinetics of metal removal from uranium mill tailing effluents," in BioProcessing, R. Smith and M. Misra, Eds., p. 339, TMS, 1991.

[105] O. Chaalal, A. Y. Zekri, and R. Islam, "Uptake of heavy metals by microorganisms: an experimental approach," Energy Sources, vol. 27, no. 1-2, pp. 87-100, 2005.

[106] V. I. Groudeva, S. N. Groudev, and A. S. Doycheva, "Bioremediation of waters contaminated with crude oil and toxic heavy metals," International Journal of Mineral Processing, vol. 62, no. 1-4, pp. 293-299, 2001. 

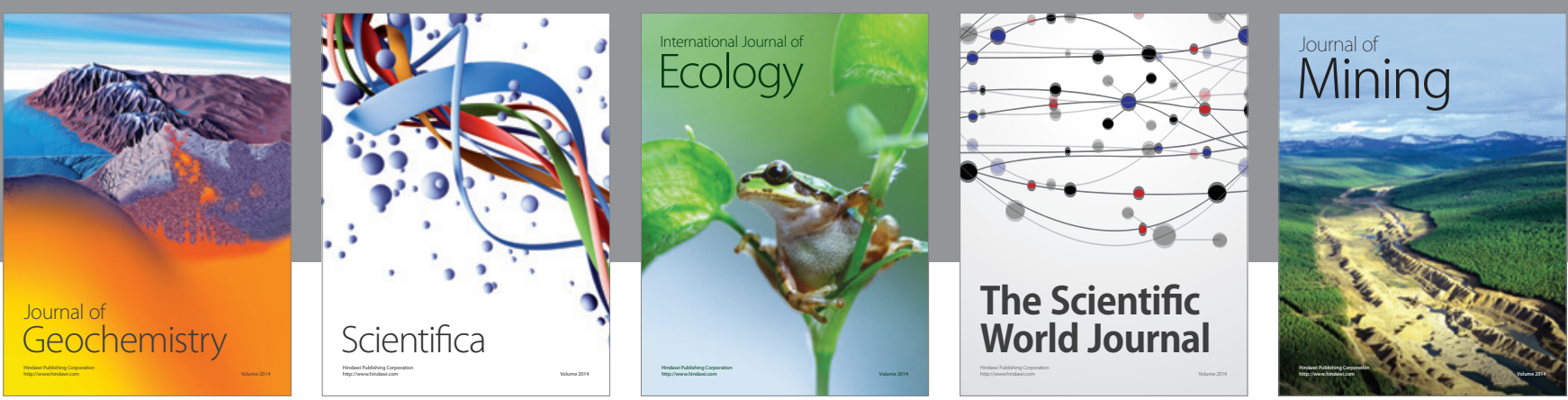

The Scientific World Journal
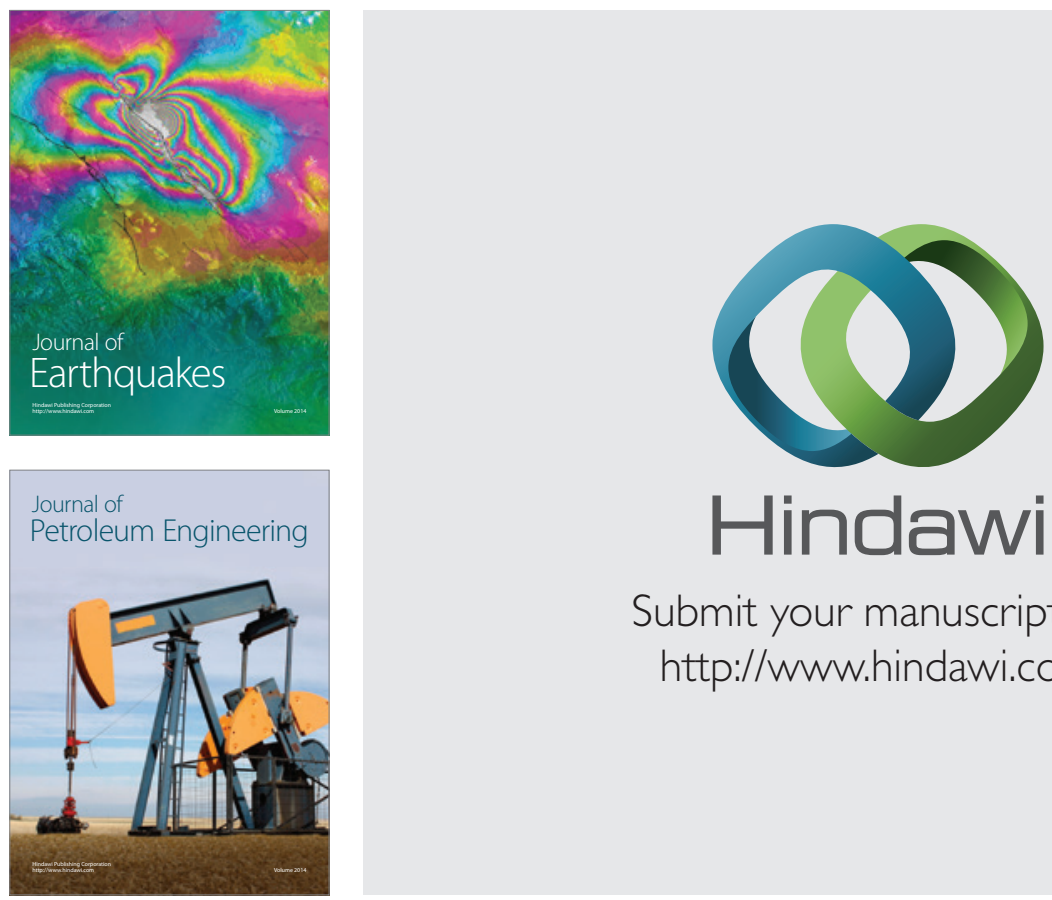

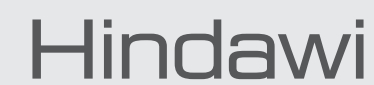

Submit your manuscripts at

http://www.hindawi.com
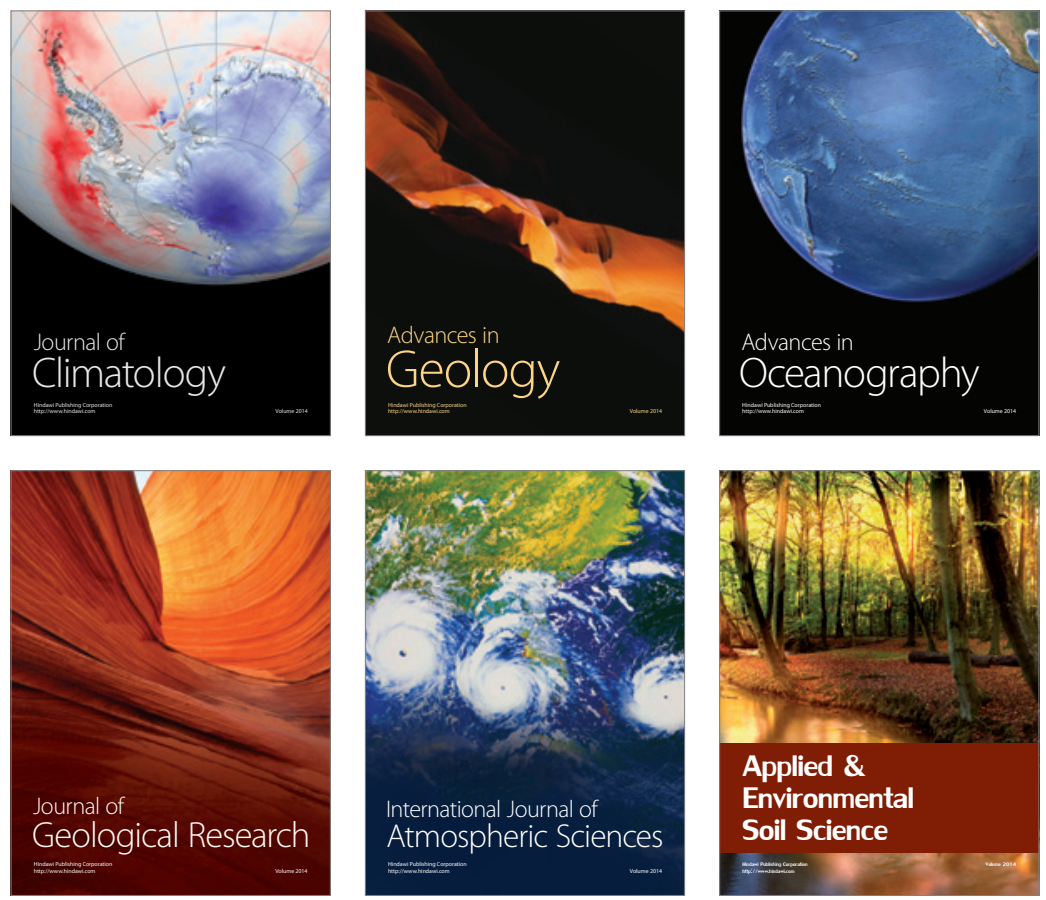
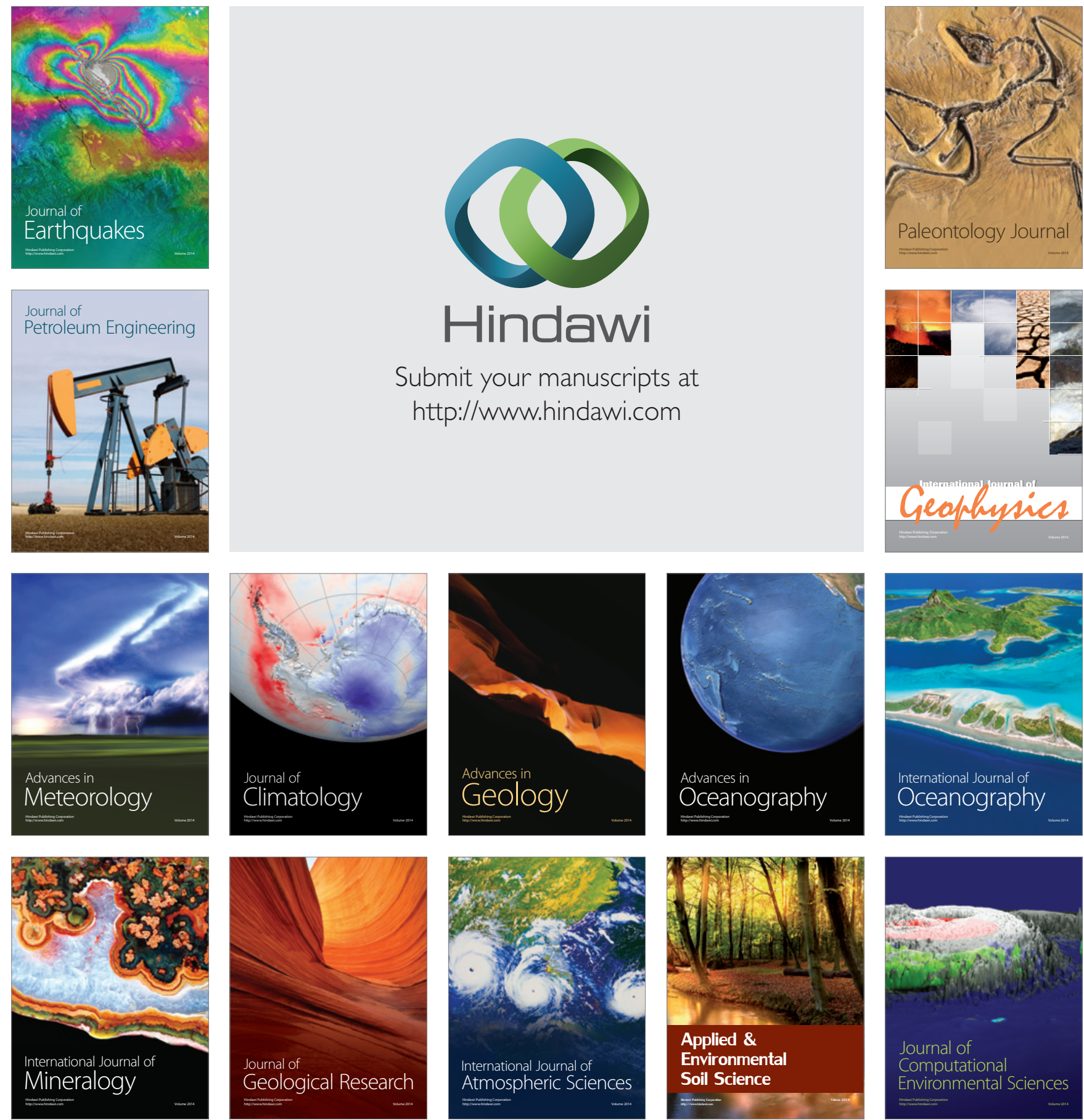